\title{
Research on the Optimization of the College Students' Ideological and Political Education under the Influence of the Social Thoughts
}

\author{
Dan Wang \\ School of Marxism, Sichuan University, Chengdu, Sichuan Province, 610065, China \\ Wangdan19860@163.com
}

\begin{abstract}
Keywords: The social thoughts; College students; Ideological and political education
\end{abstract}
\begin{abstract}
On the one hand, the home, social and school environment on college students' developing course offer a unique opportunity to promote wide spreading of the social thoughts. On the other hand, the social thoughts have also had the positive and negative influence on the college students. Through analyzing the college students' ideological and political education under the influence of several concrete social thoughts, the article propounds the viewpoint that that we must do a good job in classroom teaching, practice teaching and campus cultural construction if we want to proceed with optimizing and improving the college students' ideological and political education under the influence of the social thoughts.
\end{abstract}

\section{Introduction}

With the deepening of reform and opening up, China's economic compositions, material profit cultural needs and lifestyle become more diverse. Therefore, people's awareness becomes apparently diversified. Against this background, varieties of the social thoughts have emerged in China. The conflict of different social thoughts has produced broad but strongly effect on the present college students than ever before. The complicated and changing social thoughts inevitably have a dual influence on the college students: however, the social thoughts have caused confusion in value judge and ideal and faith of the college students while inspire their passion and activity. For this reason, how to take the positive and effective measures to deal with the challenges are what the colleges focus on in the college students' ideological and political education.

\section{The relationship between the social thoughts and college students}

The appearance of the social thoughts is the result of the diversified social development. Meanwhile, it is also tied with the college students. On the one hand, the home, social and school environment on college students' developing course offer a unique opportunity to promote wide spreading of the social thoughts. On the other hand, the social thoughts have also had the positive and negative influence on the college students.

\subsection{The college students' developing environment provides condition for wide spreading of the} social thoughts

The home, social and school environment are the main background of the growth of college students. It is precisely under those factors that the present college students get an independent opinion in their mind and thought. These unique insights and ideas tally with the various social thoughts. So the college students have become the dissemination of the social thoughts carrier.

First of all, the home environment is the essential road of wide spreading of the social thoughts by the college students. Among the home, social and school environment on college students' developing course, the home environment is the environment which influence the college students early and directly. Therefore, it may influence the college students deeply and thoroughly. Currently, influenced by family planning, most of the college students are the only child of their family. The excessive permissiveness of parents has created individualism. Besides, the increasing of the divorce rates has also created ruthlessness, loneliness and suspicion among the part of college 
students. What's more, some parents have usually overemphasized and neglected morality in family education, which lead to some college students take pride only in having money. In a word, some college students have the following characters, at least in this context: pursue character; different; self-centred; lacking in team spirit. But it is undeniable that the college students are also Independence and self-confidence. All the above characters are accordant with hedonism and money worship and so on, and to lay the ideological foundation for wide spreading of the social thoughts.

Secondly, the social environment is the major factor of wide spreading of the social thoughts by the college students. For one thing, china has appeared some social problems gradually, for example, social stratification fast, income gap and corruption and so on. All these cause some college students aroused suspicion about mainstream ideology. For the other thing, the introduction of western culture lay the ideological foundation for wide spreading of the social thoughts, such as Western diet cultures and western holidays and so on. All the traditional and the modern, rational and irrational, advanced and backward are intertwined, which bring along impulse on the college students.

Thirdly, the school environment is the important factor of wide spreading of the social thoughts by the college students. For the college students have a restless mind, it is very easy for them to accept new things, forming a new value idea. Some colleges are not paying enough attention to students' comprehensive qualities and practical caliber, and make much account of students' grading in school, leading to some students lack the ability to discern the difference between the correct thoughts and the wrong thoughts.

\subsection{The social thoughts have the positive and negative influence on the college students}

The social thoughts are kinds of social awareness, which play a huge role in guiding people in real-life situation. The social awareness has the correct part and the wrong part, so the social thoughts also have the correct part and the wrong part. Thus, the social thoughts will have a different impact on the college students.

On the one hand, the correct social thoughts have the positive influence on the college students. The correct social thoughts breathe the spirit of the age so that the college students can use them to guide their living and working. On the other hand, the wrong social thoughts have the negative influence on the college students. The wrong social thoughts are the distorted reflection on the social reality so that which can lead to the belief crisis occurring in the college students. On the whole, there is strong negative influence on the college students brought by the diversification of social thoughts.

\section{The social thoughts have brought new challenges to college students' ideological and political education}

As mentioned, the college students have been the dissemination of the social thoughts carrier, and the social thoughts have the strong negative influence on the college students. Therefore, we must face the fact that the social thoughts have brought new challenges to college students' ideological and political education. These challenges are shown as follow:

\subsection{Some college students began to have suspicions of Marxism}

The first issue is that the college students began to have suspicions of Marxism in the process of the college students' ideological and political education. Marxism is scientific truth, the core and the essence of socialistic and the guiding thought of CPC. The education of Marxism belief is the core and foundation of college students' ideological and political education. But as the social thoughts rapidly developed, Marxism began to lose its original glamour and cohesive force gradually below the shock with the social thoughts. Some college students produce to the Marxism belief are skeptical, are confused. Even some part of college students give up the Marxism and transfers believes in the authority, the money, the religion and so on.

3.2 College students' individual difference increase the difficulty of the college students' ideological and political education

Today, the college students' individual difference hastens the multiplication. The reality not only 
makes the college students' ideological and political education more difficult, but impairs the effect of it. The characteristic development of college students is a good thing for training college students. But college students live in this age, their thinking has not yet fully formed, and their world outlook and values have not fully finalized. It's easy to the fault of college students' mind. Accompanied by the strength of college students' individual difference, it is difficult for the college students to adopt the opinions what are taught in the classroom about Marxism. And what's worse is that the college students breed and encourage the individualism and money worship while lack of sense of social responsibility, community spirit.

\section{The effective ways to strengthen the college students' ideological and political education}

Facing the existing problems about the college students' ideological and political education, the article put forward some proposals to optimize the problems step by step.

\subsection{Strengthening the study of Marxism itself is the most basic measure to optimize the college} students' ideological and political education

First of all, it is necessary for any teacher at college to strengthen the study of Marxism itself. The education of Marxism is the core and foundation of college students' ideological and political education. The profound understanding and the comprehension of the essence of Marxism is the key which we strength the core and foundation of college students' ideological and political education. If cannot understand the Marxism completely and deeply, in addition, the college teachers can't master their classroom, but to persuade college students by Marxism. Through the theory of Marxism study, in particular, incorporating the reality, Chinese traditional culture and the socialist core value system, enhance the Marxism to be persuasive.

\subsection{Strengthening the study of social thoughts themselves is another measure to optimize the college students' ideological and political education}

The college students' ideological and political education has the existing problems not just because of the lacking of study on Marxism but because we overlook the study of social thoughts. For this fault, it could be improved in the later study and teaching by paying equal attention to the social thoughts and the Marxism. Research on the social thoughts is an important step to construct Marxism and optimize the college students' ideological and political education. The social thoughts are also right and wrong. We can draw a distinction between the right social thoughts and the wrong social thoughts only by the in-depth research and analysis. Only then based on these, we can further point out the nature of the wrong social thoughts and give some useful suggestions to the college students how to avoid being dragged by the wrong thoughts.

\subsection{The college education should also pay more attention to training college students' all-round development}

The typical reason for these existing problems about the college students' ideological and political education is that the low of the comprehensive quality of college students. Since long ago our school education highly focusing on the scores is worse than morality, personal qualities and other abilities. And China's present family education overly emphasizes the grade. The major problem they have caused is the low of the comprehensive quality of college students, particularly in the ability of distinguishing between right and wrong. In this day and age of social thoughts pluralism, some kinds of social thoughts are extremely confusing that could lead to great harms to the college students if they show a lack of judgment. So it is a very pressing request to strengthen quality-oriented education in college. We must promote the development of college students' judgment by improving effectively college students overall quality. Only thus can the future of the college students' ideological and political education be benefited.

4.4 Reform and perfection of the college students' ideological and political education in college

Teaching is the direct way of optimizing the college students' ideological and political education. So it requires college to be good at rethinking their traditional teaching.

The first of the problems of traditional teaching is that we pay more attention to the teaching process, ignoring college students learning process in the college students' ideological and political education. So the changing of the concept of teaching is very important to improving the quality of 
the college students' ideological and political education. We have stressed the development of responsibility of college teachers and almost simultaneously cultivated the development of responsibility of college students. Only when both college teachers and students play a role together, it is beneficial to improving teaching efficiency in the college students' ideological and political education.

The second of the problems of traditional teaching is that we neglect individual difference of college students in the college students' ideological and political education. China is a society which has a quite discrepant in its history and today. These differences display many aspects: language, food, culture, the level of economic development, and rural and urban areas and so on. Because of the differences of society, the differences among the college students are very obvious. It requires the college teachers to understand their teaching objects and objects' individual difference, to teach objects through many ways, and to meet the different demand of the students'.

The third of the problems of traditional teaching is that the emotional communication between college teachers and students is far from enough in the college students' ideological and political education. Under the influence of all kinds of social thoughts, showing humanistic concern for the college students is very important in the college students' ideological and political education. For example, with profound transformation in society, lots of single-parent families appear in China. The special family environment has an important influence on these students who live in single-parent families. Students of single-parent families have the difference of thoughts more or less than the students who have been rising in normal households. In addition to the most basic of knowledge interaction, the college teachers must pay more attention to the communication on the emotion, or even the latter become the subject of the college students' ideological and political education..

\section{Summary}

From the above analysis, we can see the social thoughts and the college students' ideological and political education are mutual restraint and mutual penetration. The social thoughts are accompanied by the changing of society, so they must exerts great influence on the college Students. Considering the prevention and elimination of disadvantages caused by the social thoughts, the college students' ideological and political education is also a focus of college education which is necessary.

\section{References}

[1] Li Bensong. The Dual Effect of Social Thoughts On the Ideological and Political Education of College Students [J]. Education and Teaching Research, 2010, 10,37-39.

[2] Wen Daji, Luo Yiping. Lead the Ideological and Political Education [J]. Lanzhou Journal with Socialist Core Value System, 2010, 9, 139-141.

[3] luo Fengmei. The Investigation and Analysis of the Influence of Democratic Socialism Thought on College Students [J]. Higher Education Forum, 2011,8,13 - 15.

[4] Yao Xichang, Liu Qiang. The Way to Cultivate College Students' National and Innovative Spirit [J]. Economic Research Journal, 2011, 3,270-271.

[5]Zhang Yi, Jiang Xiule. The Predicament and Outlet of Ideological and Political Work in Colleges Under consumerism[J]. theory Herald, 2012,2,72 - 75. 